\title{
Spiritual Development in Social Context: The Role of Christian Psychotherapy in the Formation of Identity
}

\author{
Naum Ilievski \\ Prof., PhD, Faculty of Psychology, International Slavic University \\ "Gavrilo Romanovich Derzhavin", Sveti Nikole, Macedonia \\ Angelina llievska \\ MD, Psychotherapist, Psychiatrist \\ Private Practice, Skopje, Macedonia
}

\begin{abstract}
Spiritual growth and development enable complete self-actualization. In the three stages of spiritual development - described in Christian psychotherapy and based on a practical spiritual life established in Christian patrology - man from an individual becomes a person. He builds his identity during this process. The main goal of this paper is to represent the practical aspect of spiritual Christian life and its impact in a social context. In addition, it offers a representation of the spiritual development process - a model in Christian psychotherapy, as well as a description of each stage at which spiritual identity is formed. It is a descriptive paper where the basic methods of this process are elaborated: establishing a personal relationship with a spiritual father - psychotherapist, implementing the FCP and metanoia. Analysis of identity is made by utilizing two dimensions: personal and social one. The concept of personality is profoundly connected with the ego, identity, self and identification. Identification outside of the Divine Person with partial forms of existence leads to individual and social splitting, and polarization of particles. Building a spiritual identity enables formation of personality that exists out of their spiritual self and builds a pastoral relationship in all life areas: personal, family and social. A spiritually realized person - out of the borders of individual script - is socially useful, creative and functional in the wider social context.
\end{abstract}

Keywords: spiritual development, social context, spiritual identity, spiritual self, autonomy

\section{Introduction}

The spiritual personality development is not a magical act (if you eat from the fruit, you will become like gods - cf. 1 Gen. 3, 4), but it is a process of growth and development - in obedience (Митрополит Струмички Наум, 2018).

This paper gives a description of this process from an evolutionary perspective as a concrete development model with stadia and stages of maturation. In addition, the description is made in relation to two dimensions: the individual and the social one. The subject of interest is creation of a spiritual aspect of identity and the role of Christian psychotherapy in the spiritual development process.

Some of the personality development theories in the domain of psychology regard spiritual development as the highest level in the general adult development. This is represented in Erik Erikson's theory of psychosocial development (Erickson, 1998, as cited in Sadock \& Sadock, 2005, p. 746).

Within the frames of transpersonal psychology, whose founder is Abraham Maslow, spiritual development - besides as an evolutionary stadium - is also considered as an element of spiritual transformation and the individual's capacity for selftranscendence (Maslow, 1971, p. 259).

According to Christian psychotherapy, love ethos is the essence of the practical Christian spiritual life. Spiritual identity in Christian psychotherapy is built according to this central premise. Thus, a personality is formed that is not only individually 
responsible, but also possesses full self-awareness, pastoral intrapersonal and interpersonal relationships, as well as a wider social responsibility.

\section{Psychological Dimension of Identity - Relations to the Individual and the Ego}

Many authors have reviewed the concept of identity, its meaning and development. It is defined as "the fact of being who or what a person or thing is" (Oxford Advanced Learner's Dictionary, 2005). Etymologically, the term originates from the Latin root idem, meaning the same.

Identity may be explored and defined from several aspects: social, psychological, philosophical, anthropological and theological. It is deeply interwoven with the concepts of the individual, the personality, the ego, the self and the psychological defense mechanism - identification.

As opposed to the person, which is an authentic and complete human existence, according to the structural tripartite model of psychoanalysis (id, ego, superego - Freud, 1923), the individual is a mode of existence only at the level of the psychological structures of the psyche that is realized through the secondary function of the mind - the intellect (llievski, 2015, p. 168).

The individual has formed ego identity with ego limits, which enables individual functioning and differentiating from other beings. The individual establishes a dynamic equilibrium between $I-$ the others and $I-$ the world. Vital functioning is provided through equilibrium between the intrapsychic world and the exteropsyche at one level, and congruence in the relation between the self and the imago at a deeper personal level (described by Jung with the term mask - Jung, 1967). The individual is in the domain of the anthropocentric and egocentric model.

According to Christian patrology and anthropology, man is predetermined in his own center - the spiritual heart, that is, he is predetermined for a theocentric model of existence (llievski and llievska, 2018, p. 210). This model is achieved through a continuous, practical spiritual life, which aids spiritual identity to be developed; the ultimate goal is identification and uniting with the Archetype of good - God, which is the highest stage in spiritual development.

In modern psychotherapy, identity is reviewed from the aspect of its psychological dimension. The Italian therapist M. T. Tosi (2018, pp. 139-151) proposes that personal identity is based on two dimensions: the individual and the interpersonal one. "Personal identity is based on two fundamental dimensions that deserve special attention in psychotherapy: one that grounds personal identity in autobiography along with core needs, wishes, and intentions, and another that sees moral traits - one's sense of interpersonal responsibility - as the most important part of personal identity as recognized by others."

\section{Spiritual Dimension of Identity - Autonomy beyond the Self}

To be a person with an established identity implies complete identity formation - not only at a psychological, but also at a spiritual level. The person with a formed spiritual identity reaches the level of awareness, freedom and autonomy.

According to the Transactional analyst E. Berne (1966), the healing of the client - after a successfully terminated psychotherapeutic process - is a "script cure," that is, healing of his individual scenario and breaking up the limited frames of that given life script ("unconscious life plan"). This kind of healing is a Bernian understanding of autonomy and its components - awareness, spontaneity and intimacy (Berne, 1972, p. 438).

Autonomy is the key element in the formation of man and his spiritual identity. It is closely connected to the concepts of the spiritual self, the personality and its realization in freedom. Autonomy enables openness to the spiritual dimension and a further unobstructed personal growth. According to Kandathil G. and Kandathil C. (1997, pp. 24-29), who implemented the spiritual component into psychotherapy, "autonomy is an open door towards spirituality."

Spiritual identity is closely connected to the spiritual self. The self is an essential manifestation, whereas the identity is man's individual manifestation. In a certain way, the self manifests itself through the identity and serves to its functioning, too. 


\section{Spiritual Identity Development Model}

In Christian psychotherapy, identity implies identity of a person that is spiritually realized through his spiritual self. The creation of spiritual identity is a process with synchronized phases that follow the harmony of spiritual life through the threestage spiritual development.

The process of identity-building is a two-way process, from a person to a Person. The individual - through spiritual growth, the three-stage development and the process of establishing a personal relationship with his spiritual father (psychotherapist) - builds his personal relationship with God. Direct identification with the Image of the Creator (God) takes place during that process.

\begin{tabular}{|c|c|c|c|c|c|c|c|c|}
\hline $\begin{array}{l}\text { Stages of } \\
\text { spiritual } \\
\text { development }\end{array}$ & $\begin{array}{l}\text { What is the } \\
\text { prayer like }\end{array}$ & $\begin{array}{l}\text { What is } \\
\text { purified }\end{array}$ & $\begin{array}{l}\text { What is stressed } \\
\text { in } \\
\text { the struggle }\end{array}$ & $\begin{array}{l}\text { The temptations } \\
\text { are mainly }\end{array}$ & $\begin{array}{l}\text { The mode of } \\
\text { organization of } \\
\text { monastic life }\end{array}$ & $\begin{array}{l}\text { Clerical } \\
\text { rank }\end{array}$ & Obedience & Love \\
\hline PURIFICATION & $\begin{array}{l}\text { oral or with } \\
\text { the mind }\end{array}$ & $\begin{array}{l}\text { the energy } \\
\text { of the mind }\end{array}$ & $\begin{array}{l}\text { placing of } \\
\text { the mind in a } \\
\text { process of } \\
\text { healing (ascetic } \\
\text { humility) }\end{array}$ & $\begin{array}{l}\text { from within } \\
\text { (due to the } \\
\text { captivity to } \\
\text { passions) }\end{array}$ & coenobium & deacon & $\begin{array}{l}\text { absolute or } \\
\text { blind } \\
\text { obedience }\end{array}$ & eros \\
\hline $\begin{array}{l}\text { II. } \\
\text { ILLUMINATION }\end{array}$ & \begin{tabular}{|l} 
ascetic \\
mind-and- \\
heart \\
prayer
\end{tabular} & $\begin{array}{l}\text { the essence } \\
\text { of the mind } \\
\text { (which is in } \\
\text { the heart) }\end{array}$ & $\begin{array}{l}\text { keeping of the } \\
\text { mind within the } \\
\text { heart and love } \\
\text { toward one's } \\
\text { enemies }\end{array}$ & $\begin{array}{l}\text { from outside } \\
\text { (through people) }\end{array}$ & skete & presbyter & $\begin{array}{l}\text { depends on } \\
\text { the level at } \\
\text { which one's } \\
\text { spiritual } \\
\text { father is }\end{array}$ & $\begin{array}{l}\text { friendship } \\
\text { (closeness) }\end{array}$ \\
\hline GODLIKENESS & $\begin{array}{l}\text { unceasing } \\
\text { or graceful } \\
\text { mind-and- } \\
\text { heart } \\
\text { prayer }\end{array}$ & $\begin{array}{l}\text { deification } \\
\text { of the whole } \\
\text { man - both } \\
\text { body } \\
\text { and soul }\end{array}$ & $\begin{array}{l}\text { prayer and } \\
\text { mourning for } \\
\text { the whole } \\
\text { world }\end{array}$ & $\begin{array}{l}\text { from outside } \\
\text { (through people } \\
\text { and from the } \\
\text { demon himself) }\end{array}$ & hermitage & bishop & not to a man & love \\
\hline
\end{tabular}

\section{Fig. 1. - Table of the Harmony of the Ascetic-hesychastic Struggle}

(according to which everyone can find their place on the ladder of spiritual development, become aware of and reconcile the mode of his personal struggle in accordance with his spiritual development and position in the Church)

The stages of formation of spiritual identity are described below (llievska and llievski, 2018):

In the first stage of spiritual development, man is an individual and he identifies himself with his spiritual father psychotherapist. His spiritual identity is in a beginning phase.

In the second stage of spiritual development, man becomes a person and identifies himself with the Creator Himself - God. He has already built his spiritual identity.

In the third stage of spiritual development, the process is beyond the identification level. The person IS. There is no identification anymore; in this stage, it has occurred a complete unity - likeness of the person to the Image. Spiritual analogy is manifested when man is in God and God is in man; a complete spiritual identity is built.

\section{Elements of Spiritual Development}

The process of spiritual growth and development is based on the following crucial components (llievska and llievski, 2018):

Building a personal relationship (with a spiritual father - psychotherapist)

Entering into obedience

Appliance of the FCP method

Metanoia (Greek: $\mu$ ctávola - change of mind). 
The method of Five Control Points (FCP) is a core concept in Christian psychotherapy that is pivotal in the practical spiritual Christian life (systematized by the author - llievski, 2017, pp. 93-98). These are the following:

Acceptance (accepting negative life events as a gift of God). The key is in acceptance. He who accepts negative life events correctly has reached the end before setting out on his journey. It is the main turning point as an initial position. A sign that the situation is accepted as a gift is when without changing itself at all - except our attitude towards it - it becomes to us a source of joy, consolation and grace.

Thanksgiving (giving thanks to God). Gratitude as a positive emotional and spiritual state that enables the person an unhindered access to the greatest power of the spiritual self, as well as building a positive and constructive attitude towards various life occasions.

Self-discernment (self-examining with a humble self-conscience). Keeping the locus of control to oneself, with an insight into one's own conduct and understanding his role into concrete life situations.

Quiescence (stillness with a behavioral peacefulness). Not showing outwardly with some gesture that one is being tempted.

Prayer (not as a battle against negative life events, but as a continuous struggle of building union with God). Prayerfully collecting its energy into God-in the heart, the mind comes to knowledge of God and realizes its own primary function. On the other hand, when scattering its energy through the senses in the world, the mind realizes its secondary function as intellect.

In contrast to the most common methods in modern psychology for coping with negative life events that bring imbalance in the psychosocial equilibrium, the FCP method is a referential framework; the FCP are merely referential and serve for a quick and efficient practical self-estimation - whether one acts in the right manner when he faces serious life challenges.

By accepting these challenges, the process is realized at a spiritual level and results in personal growth and development of the individual into a person. In all other cases of non-acceptance, the individual goes through a long process of grief and grieving (Kübler-Ross, 1969, p. 91), at the same time exhausting his mental energy and defense ego mechanisms.

Hence, there is an essential difference between the ego and the spiritual self. A challenging question is posed: "What kind of being is man and what is the development to a perfect man supposed to be?" If it is taken into consideration only his biological, psychological and social dimension, there would hardly ever be offered profound, let alone full answers.

According to the theories of personality in psychology, man has developmental tasks analogous to each developmental phase; correct development implies that man actualizes himself at different stages and is realized by achieving the psychological goals. Thus, man achieves psychological growth and development, and is formed into a psychologically healthy person, with an inward equilibrium and an outward healthy functioning in relation to the reality, the other people and the world surrounding him.

In Christian psychotherapy, the basics of Christian anthropology are employed. According to these basics, man is created in the Image of the Creator - God; accordingly, each man has a potential for spiritual growth, self-realization and selfactualization as a supreme reach in one's personal existence. Therefore, man is predetermined to reach the third stage of spiritual development - deification or Godlikeness. Undoubtedly, spirituality plays a key role in man's formation and development.

\section{Social Dimension of Spiritual Life}

Human identity is characterized by uniqueness, singularity, diversity, and it is susceptible to dynamic changes in the complex relations of the wider social context: family, community and society.

Generally speaking, spirituality has a positive impact in the formation of one's personality and identity. It activates the meaning of life, the sense of purpose and belongingness, the transpersonal experience and the transcendent feeling of universality.

This is a sufficient reason to make life creative process, whose existence is lifted to a higher, spiritual level, where man becomes a person - what he has ontologically been predetermined for, since his creation. 
A person with formed spiritual identity has a pastoral approach towards other people - interpersonally, in all life areas: personal, family, social, and the wider social context - national and state. Such a person is socially responsible, useful and able to implement positive values and principles, not only the moral and ethical ones, but also the aesthetic and spiritual values, and contributes to an overall social prosperity.

\section{References}

[1] Berne, E. (1966). Principles of Group Treatment. New York, NY: Grove Press.

[2] Berne, E. (1972). What Do You Say After You Say Hello? The Psychology of Human Destiny. New York, NY: Grove Press.

[3] Erikson, E. H., Erikson, J. M. (1998). The Life Cycle Completed: Extended Version. New York, NY: W. W. Norton \& Company.

[4] Erikson, E. H. In: Sadock, B. J., Sadock, V. A. (2005). Kaplan \& Sadock's Comprehensive Textbook of Psychiatry, Vol. 1 (8 $8^{\text {th }}$ ed.). Philadelphia, PA: Lippincott Williams \& Wilkins.

[5] Freud, S. (1923). The Ego and the Id. In: Strachey J. et al. (Trans.), The Standard Edition of the Complete Psychological Works of Sigmund Freud, 19. London, England: Hogarth Press.

[6] Ilievski, N., Metropolitan of Strumica (2015). Basics of the Ascetical (Christian) Psychotherapy, Contributions. Sec. Med. Sci., 36(1), MASA, 165-173.

[7] Ilievski, N., llievska, A. (2017, Sep.-Dec.). Sociological Dimensions of the FCP Method according to Christian Psychotherapy in Coping with Stress and Suffering, European Journal of Social Sciences Education and Research, 11(1), 93-98.

[8] Ilievska, A., Ilievski, N. (2018). Transactional Analysis and Christan Psychothetapy - Integrated Approach to Human Psycho-spiritual Development (Unpublished full paper).

[9] Илиевски, Н., Илиевска, А. (2018, April). Психолошка глад, консумеризам и мас-интројекција - два модела на живот, Меѓународен дијалог: Исток - Запад (психологија и образование), 5(3), 209-212.

[10] Jung, C. G. (1967). Two Essays on Analytical Psychology. In: Collected Works of C. G. Jung, 7, Princeton, New Jersey: Princeton University Press.

[11] Kandathil, G., Kandathil, C. (1997). Autonomy: Open Door to Spirituality. Transactional Analysis Journal, 27(1), 24-29.

[12] Kübler-Ross, E. On Death and Dying [Kindle version]. Retrived from http://www.amazon.com

[13] Maslow, A. H. (1971). The Farther Reaches of Human Nature. New York, NY: The Viking Press.

[14] Metropolitan Nahum of Strumica. Only One Thing Is Needed [Kindle version]. Retrived from http://www.amazon.com

[15] Митрополит Струмички Наум (2014). Надминување на дуализмот. Велјуса, Македонија: Манастир Воведение на Пресвета Богородица Елеуса.

[16] Митрополит Струмички Наум (2015). Премин од душевност во духовност. Велјуса, Македонија: Манастир Воведение на Пресвета Богородица Елеуса.

[17] Митрополит Струмички Наум (2018, October 27). Тие ги имаат Мојсеј и Пророците; нив нека ги слушаат. Retrieved from http://mpc.org.mk/MPC/SE/vest.asp?id=6979

[18] Oxford Advanced Learner's Dictionary (7 $7^{\text {th }}$ ed.). (2005). Oxford, England: Oxford University Press.

[19] Sadock, B. J., Sadock, V. A., Ruiz, P. (2015). Kaplan \& Sadock's Synopsis of Psychiatry: Behavioral Sciences/Clinical Psychiatry (1 $11^{\text {th }}$ ed.). Philadelphia, PA: Wolters Kluwer.

[20] Tosi, M. T. (2018). Personal Identity and Moral Discourse in Psychotherapy. Transactional Analysis Journal, 48(2), 139-151. 